\title{
WEAR RESISTANCE OF DENTAL MATERIALS WHICH ARE USED FOR ANTERIOR TEETH RESTORATIONS
}

DOI: 10.36740/WLek202008117

\author{
Igor V. Yanishen ${ }^{1}$, Iryna M. Tkachenko², Petro M. Skrypnikov², Petro A. Hasiuk ${ }^{3}$ \\ 'KHARKIV NATIONAL MEDICAL UNIVERSITY, KHARKIV, UKRAINE \\ 2UKRAINIAN MEDICAL STOMATOLOGICAL ACADEMY, POLTAVA, UKRAINE \\ IIVAN HORBACHEVSKY TERNOPIL NATIONAL MEDICAL UNIVERSITY, TERNOPIL, UKRAINE
}

\begin{abstract}
The aim of this study was to compare the wear resistance of such restorative materials as composite resin, feldspathic ceramic, leucite glass ceramic with intact enamel and to draw an analogy with some similar researches.

Materials and methods: In this research 20 extracted human teeth (maxillary incisors) without fillings and carious cavities were used as samples. All samples were disinfected and stored in saline in order to prevent dehydration. Teeth roots were cut off for the measure of fixation on an organic glass plate using chemically polymerizable resin. If necessary, the teeth were also cut on their lateral sides in order to give them equal size. The samples were placed in a frame-holder, located on the lever of the machine MI-2, which determines abrasion resistance under slipping.

Results: The research has revealed that the average wear resistance of natural teeth was $122,67 \pm 4.9 \mathrm{~J} / \mathrm{mm}^{3}$ (Tab 1). The archived result overcomes dental composite resin twice more $\left(62.8 \pm 1.21 \mathrm{~J} / \mathrm{mm}^{3}\right)$, feldspathic ceramic 6.5 times more $\left(16.32 \pm 1.2 \mathrm{~J} / \mathrm{mm}^{3}\right)$ and leucite ceramic over the half $\left(73.79 \pm 3.12 \mathrm{~J} / \mathrm{mm}^{3}\right)$

Conclusion: Thus, according to this performed research and the analysis of the relative literature sources it can be stated that dental composite resin and leucite ceramics may be proposed as the materials of choice for anterior restoration of teeth. They have shown the good wear resistance and tolerance to antagonizing natural teeth.
\end{abstract}

KEY WORDS: leucite, composite resin, dental porcelain

\section{INTRODUCTION}

The principle of biomimetics in dentistry is associated with balanced luminosity, translucency, opacity, wear resistance of artificial restorations of teeth being maximally similar to natural dentin and enamel. Restorative material which are used for anterior restorations nowadays should resemble hard tissues of teeth both from mechanical and aesthetic point of view. The ability of restored anterior teeth to stay as worn as natural tooth enamel and not to abrade excessively antagonist teeth often predefines the quality of aesthetic rehabilitation and the quality of life of patient after treatment $[1,2]$ Lambrechts et al. reported that the wear of enamel opposing enamel is approximately 20 to $40 \mu \mathrm{m}$ per year [3].

Wear of teeth is a physiological process which depends on such factors as mastication habits, food consistency, neuromuscular parameters of masticatory apparatus and material's abrasive properties of opposing teeth [4].

If the abrasive properties of restorative material differ from natural tissues the wear process may become accelerated comparing to the natural dentition [5].

Nowadays one of the challenging issues for practitioners dealing with anterior restoration is the choice of proper restorative material. The task of the dentist is not only to restore or improve aesthetics but to regain the function and to improve the quality of patients ' life on a maximal term. From the list of available restorative materials several types should be underlined. Those are light-curing composite resin, feldspathic ceramic and leucite reinforced glass ceramic $[6,7]$.

Feldspathic ceramic has been in use in dentistry for more then a century. It proved to be a very natural-looking material for tooth restoration with good mechanical properties [8], however rather abrasive to antagonists especially if unpolished [9].

All-ceramics is the restorative material which have been in dental practice for the recent twenty years. While being in practice all-ceramics have proved to be aesthetic, durable, chemical inert, bio-compatible, resistant to fractures and wear [10]. However, despite trying to solve the problem with excessive wear of enamel, all-ceramics haven 't solved this problem completely $[9,11,12]$.

According to some researchers enamel wear pattern depends on the microstructure of opposing material and different oral cavity factors [13]. However, correlation between clinical and laboratory data has revealed to be a challenging task [14].

Some investigations about wear resistance of dental ceramics when opposing intact enamel reported that dental porcelain has been described to be wear resistant against opposing restorative materials and enamel $[15,16]$. Preis et al. has found that porcelain has comparable or reduced wear 


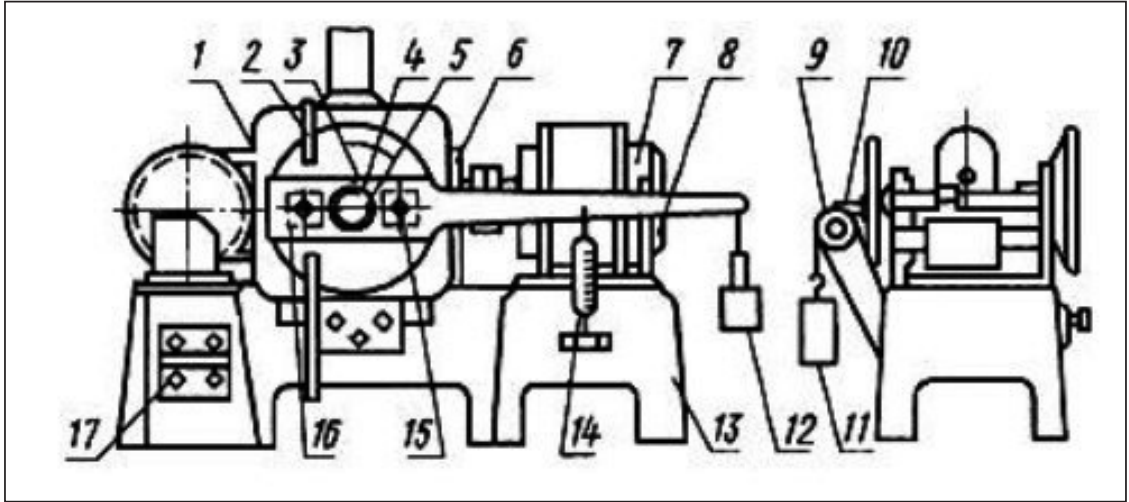

Fig.1. MI-2 testing machine (general schema). 1. Shell 2. Air duct 3. Lever 4. Disk 5. Shaft 6. Reducer 7. Electric motor 8. Clamp 9. Roller 10. Loading rod 11. Weight 12. Balancing weight 13. Frame 14. Dynamometer 15. Screw 16. Frame holder 17. Switcher

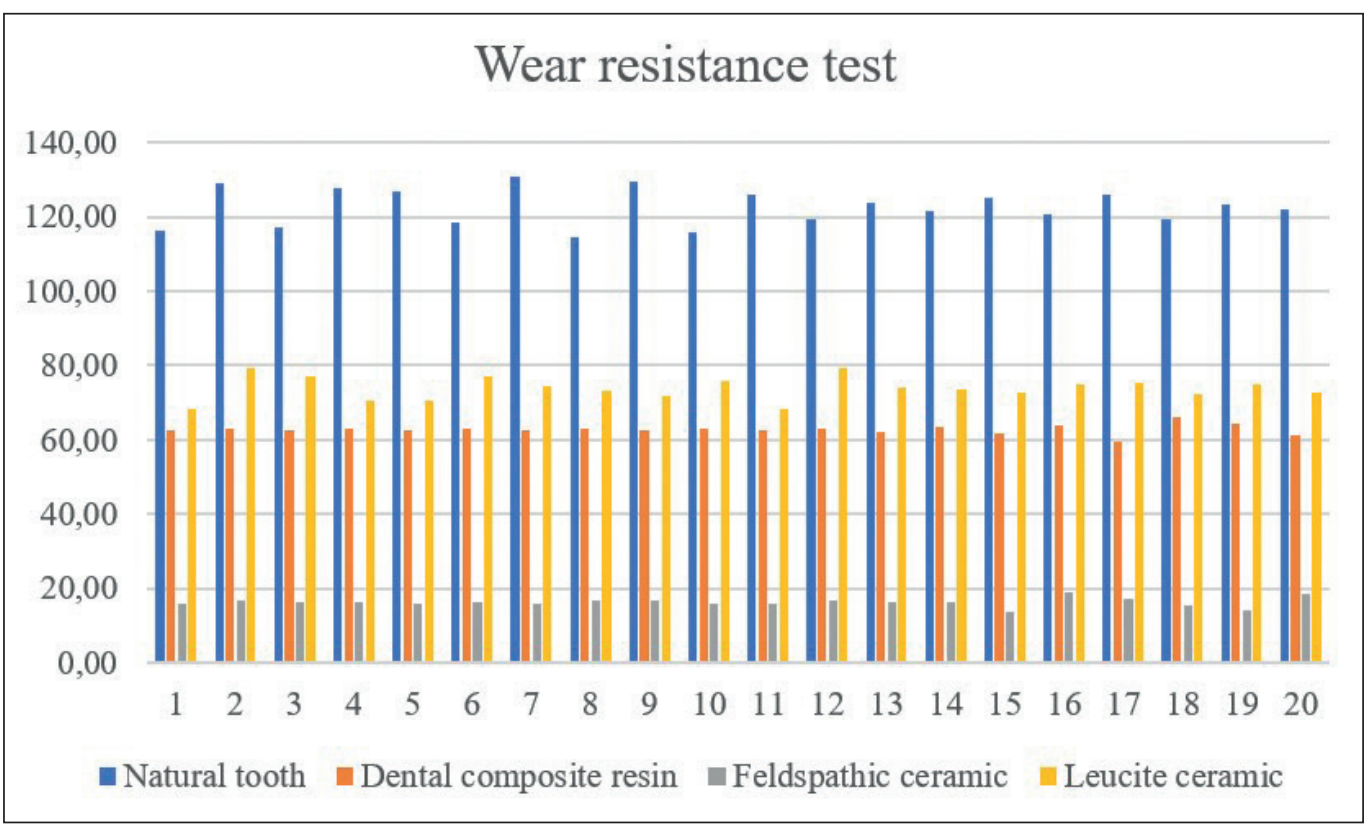

Fig. 2. Wear resistance of natural teeth in comparison with different restorative materials [22].

than enamel [16]. On the other hand, some others investigations revealed that ceramic substrates cause destructive abrasive wear of enamel [17]. Such material characteristics as internal porosities, surface defects and fracture toughness may lead to the increased loss of opposing enamel [18].

Light-cured composite resin is one of the most widespread material for anterior restoration of teeth, which has proved up to be a good alternative to ceramics due to its good aesthetic properties, predictability, affordability and rapidity of manufacturing comparing to dental ceramics, especially if applied in direct restorative technique. The capacity of composites to cause enamel wear was proved by Chapman and Nathanson and by Suzuki and Leinfelder. Nevertheless, composites have most often been reported excessively worn by enamel and/or other restorative materials $[19,20]$.

Despite having certain disadvantages (dry luster loss, water absorption, aging discoloration etc.), it remains to be the material of choice of many dentists [21].

\section{THE AIM}

The aim of this study was to compare the wear resistance of such restorative materials as composite resin, feldspathic ceramic, leucite glass ceramic with intact enamel and to draw an analogy with some similar researches.

\section{MATERIALS AND METHODS}

In this research 20 extracted human teeth (maxillary incisors) without fillings and carious cavities were used as samples. All samples were disinfected and stored in saline in order to prevent dehydration.

Before testing, the samples were degreased with ethyl alcohol and their density was determined by hydrostatic weighing.

Teeth roots were cut off for the measure of fixation on an organic glass plate using chemically polymerizable resin. If necessary, the teeth were also cut on their lateral sides in order to give them equal size. The samples were placed in a frame-holder, located on the lever of the machine MI-2 (Fig.1), which determines abrasion resistance under slipping. The force applied to the lever was equal to $29.4 \mathrm{~N} \mathrm{(22).}$

The wear of samples was determined after 200 rotations of the abrasive disk. At the end of testing the samples were weighed again.

Wear resistance was calculated according to this formula:

$\beta=(\mathrm{A}-$ work of friction, $J ;-$ volumetric reduce of a sample, $\left.\mathrm{mm}^{3}\right)$. 
Table.1. Detailed data on wear resistance of restorative materials.

\begin{tabular}{|c|c|c|c|c|}
\hline & Natural enamel & Dental composite resin [22] & Feldspathic ceramic [22] & Leucite ceramic [22] \\
\hline 1 & 116,30 & 62,60 & 15,90 & 68,40 \\
\hline 2 & 129,10 & 63,00 & 16,70 & 79,20 \\
\hline 3 & 117,10 & 62,70 & 16,40 & 77,30 \\
\hline 4 & 127,70 & 62,90 & 16,20 & 70,30 \\
\hline 5 & 126,70 & 62,70 & 16,10 & 70,50 \\
\hline 6 & 118,70 & 62,80 & 16,50 & 77,10 \\
\hline 7 & 130,70 & 62,40 & 16,00 & 74,60 \\
\hline 8 & 114,70 & 63,20 & 16,60 & 73,00 \\
\hline 9 & 129,70 & 62,50 & 16,90 & 71,80 \\
\hline 10 & 115,70 & 63,10 & 15,70 & 75,80 \\
\hline 11 & 126,20 & 62,60 & 15,80 & 68,30 \\
\hline 12 & 119,20 & 63,10 & 16,80 & 79,30 \\
\hline 13 & 123,80 & 62,20 & 16,20 & 74,20 \\
\hline 14 & 121,60 & 63,40 & 16,40 & 73,40 \\
\hline 15 & 124,90 & 61,80 & 13,80 & 72,60 \\
\hline 16 & 120,50 & 63,70 & 19,10 & 74,90 \\
\hline 17 & 126,00 & 59,60 & 17,20 & 75,30 \\
\hline 18 & 119,40 & 66,00 & 15,40 & 72,20 \\
\hline 19 & 123,40 & 64,20 & 14,10 & 74,80 \\
\hline 20 & 122,00 & 61,40 & 18,50 & 72,70 \\
\hline Mean & $122,67 \pm 4.9$ & $62.8 \pm 1.21$ & $16.32 \pm 1.2$ & $73.79 \pm 3.12$ \\
\hline
\end{tabular}

The results were compared with the results of the test performed by Vodoriz et al. [22] as the one that had used similar testing machine for its research. These results were consolidated into one datasheet for the sake of maximal informativity.

The results were statistically processed with paired samples t-test.

\section{RESULTS AND DISCUSSION}

The research has revealed that the average wear resistance of natural teeth was $122,67 \pm 4.9 \mathrm{~J} / \mathrm{mm}^{3}$ (Tab 1$)$. The archived result overcomes dental composite resin twice more $(62.8 \pm 1.21$ $\left.\mathrm{J} / \mathrm{mm}^{3}\right)$, feldspathic ceramic 6.5 times more $\left(16.32 \pm 1.2 \mathrm{~J} / \mathrm{mm}^{3}\right)$ and leucite ceramic over the half $\left(73.79 \pm 3.12 \mathrm{~J} / \mathrm{mm}^{3}\right)$ (Fig. 2).

Paired samples T-test has showed absolute $(\mathrm{p}=0)$ significance in all combinations of dental materials pairs

Discussion of the results and their comparison with the data received by other scientists is a challenging task according to variety of techniques used for wear resistance precision and the possible influence of different variables.

Nevertheless, some affinities should be mentioned. Passos et al. in his article reports dental composite resin to be the most resistant to abrasion and attrition, while leucite ceramics keeps second place with 65-70 $\mu \mathrm{m}$ result which is very close to the natural enamel-to-enamel wear rate in vivo results $(100 \mu \mathrm{m} /$ year $)$ [18].

Lambrechts et al. data mentions composite resin as a material which mechanical wear (50-80 $\mu \mathrm{m} /$ year) rate is very close to natural enamel but still depends on the type of the composite [23].
Etman at all also reports glass ceramic to have a friendly wear behavior on the opposing enamel (approx. $145 \mu \mathrm{m} /$ year) [24].

De Long et al. in his study of wear rate of different dental ceramics and has revealed that leucite ceramic was the most tolerant to enamel comparing with $\mathrm{Al}_{2} \mathrm{O}_{3}$ ceramics and porcelain fused to metal [9].

However, it shouldn't be forgotten that the abrasion rate significantly decreases if the tested system is found in the moist circumstance (ex. saliva) [25].

According to his investigations Park et al. recommends A-W GC2 (glass-ceramic) as a material of choice for restoration of teeth which oppose natural enamel. He also mentions IPS Empress 2 (leucite ceramic) to be the most resistant to abrasion [26].

D'Arcangelo et al. and Hudson in their works reports gold alloy restorations to have the most prominent biological characteristics from the point of view of tolerance to hard tissues of teeth as their wear rate is very close to enamel $[27,28]$.

\section{CONCLUSIONS}

Thus, according to this performed research and the analysis of the relative literature sources it can be stated that dental composite resin and leucite ceramics may be proposed as the materials of choice for anterior restoration of teeth. They have shown the good wear resistance and tolerance to antagonizing natural teeth. The last-mentioned property is crucial because 
hardness of materials doesn't always predestinate success in rehabilitation of patient. The changes of life quality of patient are supposed to be the parameter which is used for evaluation of successful treatment. Thus, it would be a reasoned prospect to evaluate how patients' life quality changes depending on the type of restoration used for dental rehabilitation $[29,30]$.

\section{REFERENCES}

1. Sulong M.Z.A.M., Aziz R.A. Wear of materials used in dentistry: A review of the literature.JProsthetDent [Internet]. 1990 Mar 1;63(3):342-9. Available from: https://doi.org/10.1016/0022-3913(90)90209-U

2. Seghi R., RosenstielS., BauerP.Abrasion of Human Enamel by Different Dental Ceramics In Vitro. J Dent Res. 1991;70:221-5.

3. Lambrechts P., Braem M.,VanherleG. Buonocore memorial lecture. Evaluation of clinical performance for posterior composite resins and dentin adhesives. Oper Dent. 1987;12(2):53-78.

4. Kim S., Kim N., Chang l., Heo S-J. A study of the effects of chewing patterns on occlusal wear. J Oral Rehabil. 2001;28:1048-55.

5. Hmaidouch R., Weigl P. Tooth wear against ceramic crowns in posterior region: a systematic literature review. Int J Oral Sci. 2013 Dec;5(4):183-90.

6. Vodoriz Y., Marchenko I., Shyndryk M., Tkachenko I. Review of treatment methods of patients with uncomplicated teeth fractures . Wiadomości Lek [Internet]. 2018;71(7):1360-4. Available from: https://www.ncbi.nlm.nih. gov/pubmed/30448811

7. Tkachenko I.M., Kovalenko V.V., Skrypnikov P.M., Vodoriz Y.Y. Reasoning of adhesive system choice for treatment of patients with increased tooth wear. Wiad Lek. 2018;71(6):1129-34.

8. Sakaguchi R., Powers J., Ferracane J. Craig's Restorative Dental Materials. In: Craig's Restorative Dental Materials. 2012. p. 467-496.

9. DeLong R.,SasikC.,Pintado M.,DouglasW.Thewear ofenamel when opposed by ceramic systems. Dent Mater. 1989;5:266-71.

10. Bona A., Mecholsky J., Anusavice K. Fracture behavior of lithia disilicate- and leucite-based ceramics. Dent Mater. 2005;20:956-62.

11. Schuh C., Kinast E., Mezzomo E., Kapczinski M. Effect of glazed and polished surface finishes on the friction coefficient of two low-fusing ceramics.JProsthet Dent. 2005;93:245-52.

12. AlbakryM.,Guazzato M.,Swain M. FractureToughness and Hardness Evaluation of Three Pressable All-Ceramic Dental Materials. J Dent. 2003;31:181-8.

13. OhW-S., Anusavice K. Factors affecting enamel and ceramic wear: A literature review. J Prosthet Dent. 2002;87:451-9.

14. Jagger D.C., Harrison A. An in vitro investigation into the wear effects of unglazed, glazed, and polished porcelain on human enamel. J Prosthet Dent. 1994;72:320-3.

15. Elmaria A., Goldstein G., Vijayaraghavan T., et al. An evaluation of wear when enamel is opposed by various ceramic materials and gold. J Prosthet Dent. 2006;96:345-53.

16. Preis V., Behr M., Kolbeck C., et al. Wear performance of substructure ceramics and veneering porcelains. Dent Mater. 2011;27:796-804.

17. Heintze S., BarkmeierW., Latta M., Rousson V. Round robin test:Wear of nine dental restorative materials in six different wear simulators - Supplement to the round robin test of 2005. Dent Mater. 2011;27:e1-e9.

18. Passos S.P., Anderson P., lorgovan G., Sami A. Enamel wear opposing different surface conditions of different CAD / CAM ceramics. Restorative Dent. 2013;44(10):743-51.

19. Chapman R., Nathanson D. Excessive Wear of Natural Tooth Structure by Opposing Composite Restorations. J Am Dent Assoc. 1983;106:51-3.

20. Suzuki S., Leinfelder K. Wear of enamel cusps opposed by posterior composite resin. Quintessence Int. 1993;24:885-90.
21. Kumhyr I.R. Porivnyal'na otsinka pryamykh i nepryamykh restavratsiy u khvorykh iz defektamy tverdykh tkanyn frontal'nykh zubiv.. [Comparative evaluation of direct and indirect restorations in patients with defects in the tooth hard tissues of anteriorteeth]. Ukrainian dental almanac. 2009;2:29-33.

22. Vodoriz Y.Y., Brailko N.N., Lemeshko A.V., et al. Vyznachennya oporu styrannya stomatolohichnykh materialiv, yaki zastosovuyut'sya pry pryamykh ta nepryamykh restavratsiyayizubiv frontal'noyi hrupy. [Determination of abrasion resistance of dental materials used for direct and indirect restorations of teeth of the frontal group]Topical problems of modern medicine: Bulletin of the Ukrainian Medical Dental Academy [Internet]. 2019 Nov 13;19(4):45-8. Available from: https:/visnyk-umsa.com.ua/index.php/journal/article/view/152

23. Lambrechts P., Goovaerts K., BharadwajD., etal. Degradation of tooth structure and restorative materials: A review. Wear. 2006;261:980-6.

24. Etman M.K., DunneS. Quantitative Measurement ofTooth and CeramicWear: Int J Prosthodont. 2008;21(3):245-52.

25. Pedro A., AntunesV. Physical-mechanical characterization of direct restorative dental materials. Universidade de Coimbra; 2011.

26. Park J., Ozturk A. Wear of Mg0-CaO-Si02-P205 -F-Based Glass Ceramics Compared to Selected Dental Ceramics. Res Lett Mater Sci. 2007;2007:5.

27. Hudson D., Goldstein G.R. Enamel wear caused by three different restorative materials. J Prothetic Dent. 1995;74(6):647-54.

28. Arcangelo C.D., Vanini L., Rondoni G.D., Angelis F.De. Wear properties of dental ceramics and porcelains compared with human enamel. J Prosthet Dent. 115(3):350-5. Available from: http://dx.doi.org/10.1016/j. prosdent.2015.09.010

29. Vodoriz Y.Y. Otsinka yakosti zhyttya u patsiyentiv iz potreboyu u likuvanni zubiv frontal'noyi hrupy [Assessment of quality of life in patients who require treatmentin anteriordentition]. Poltava;2019. Availablefrom:http://elibumsa. pl.ua/handle/umsa/11529

30. Vodoriz Y.Y., Tkachenko I.M. Otsinka yakosti zhyttya u patsiyentiv iz potreboyu u likuvanni zubiv bichnoyi hrupy. Pytannya eksperymental'noyi ta klinichnoyi stomatolohiyi[Assessment of quality of life in patients who require treatment in posterior dentition] Issues of experimental and clinical dentistry. 2019;14:26-9. Available from: http://elibumsa.pl.ua/handle/umsa/11574

\section{ORCID and contributionship:}

Igor V. Yanishen: 0000-0003-4278-5355 ${ }^{A, B}$

Iryna M. Tkachenko: 0000-0001-8243-8644 C,D,F

Petro M. Skrypnikov: 0000-0002-4473-2284 ${ }^{E}$

Petro A. Hasiuk: 0000-0002-2915-0526 ${ }^{F}$

\section{Conflict of interest:}

The Authors declare no conflict of interest.

\section{CORRESPONDING AUTHOR Iryna M. Tkachenko}

Ukrainian medical stomatological academy Shevchenko St., 23, 36011, Poltava, Ukraine tel: +380505353181

e-mail: tkachenkoirmix@gmail.com
Received: 23.02.2020
Accepted: 29.06 .2020

A - Work concept and design, B - Data collection and analysis, C - Responsibility for statistical analysis,
D-Writing the article, E - Critical review, F- Final approval of the article 